\title{
Factors Affecting Insurance Consumption in Bangladesh: A Study in Dhaka City
}

\author{
Mohammad Jamal Hossain* \\ Assistant Professor \\ Department of Business Administration, Manarat International University \\ Plot CEN 16, Road 106, Gulshan, Dhaka 1212, Bangladesh. \\ Muhammad Helal Uddin \\ College of Economics \& Management, Nanjing University of \\ Aeronautics \& Astronautics, Nanjing, China \\ Sisheng Xie \\ College of Economics \& Management, Nanjing University \\ of Aeronautics \& Astronautics, Nanjing, China
}

\begin{abstract}
This study examined factors within insurance institutional framework that affect insurance consumption in Bangladesh. Primary data were collected from 80 insurance consumers judgmentally drawn from 10 insurance companies located in Dhaka city. Data were collected on: accessibility and prompt payment of claims, knowledge of the use and importance of insurance, professional activities by those selling insurance, nature of insurance policy statement and the overall corporate image. The data were analysed using both descriptive and inferential statistics. The socio-economic characteristics of insurance consumers revealed that most of them were literate, mostly public servants, married and were still in their active ages. In accordance with our theoretical framework, our empirical results support the established relationship between insurance consumption and institutional performance. Realising these problems as they affect insurance patronage and development in Bangladesh, the study recommends a general overhauling of insurance institution framework as a way forward for the development of a vibrant insurance market in Bangladesh.
\end{abstract}

Keywords: Factors, Affecting, Insurance, Consumption

DOI: $10.7176 / \mathrm{JESD} / 10-24-06$

Publication date: December $31^{\text {st }} 2019$

\section{Introduction}

Since the end of the Second World War, the insurance industry the world over has experienced remarkable growth. Concurrent with this growth has been significant changes within the industry. The Bangladesh insurance industry is not unaffected by this general growth malady. The growth of multiple line transition, introduction of package policies, the universal banking system, grassroots insurance, the variable annuity, growth life insurance, universal life policy, changes in regulatory framework, continued expansion of the social security system and the involvement of government as a provider of private insurance are all part of the challenges with which the insurance industry must contend with (Ibok, 2006, Soon, 1996).

Although the future of insurance industry in Bangladesh appears bright, a number of unresolved problems still exist; of particular interest is the insurance marketing system, which has affected the consumption of insurance products. In Bangladesh, this problem seems to be even more pronounced because of the level of literacy of the Bangladeshi populace. Insurance has remained one of the least purchased items within the financial market. Records reveal that about only 10 percent of the Bangladeshi population have insurance of any sort (Mordi, 1990; Wilson, 2004; and Oworen, 1991).

In general, this negative marketability of insurance products has become a problem not only to the insurance industry, but has also affected economic development. The problem has existed for a long time and has increased somewhat with the sophistication of the Bangladeshi society which has grown knowledgeably in recent years (Ibok, 2006). However, the increased importance of insurance as a provider of financial services and of investment funds in the capital market is especially pronounced in developed economies whereas insurance consumption in many developing countries is still very low. Little does one wonder what will be the future of this all important industry if these problems continue unabated?

\section{Statement of the Problem}

The large variation in insurance consumption across different economies of the world raises some important questions about what are the causes of this variation and thus, what factors have affected insurance consumption? By assessing its role as a major financial intermediary, insurance has become a key source of long term capital, 
encouraging the growth of capital markets (Catalan et al, 2000; Impavido and Musalem, 2000). Indeed, several studies have found sufficient evidences to suggest that the development of insurance industry is related to economic growth (Ward and Zurbruegg, 2000; Webb, 2000; and Soon 1996). Insurance has taken on an increasing importance as a means for individuals and groups to manage their income risks (Osaka, 1992 and Njogu, 1991).

Moreso, empirical studies on changing insurance marketing on the one hand, and consumption of insurance products on the other hand in Bangladesh appears to be inadequate. As Mordi (1990) has rightly pointed out, figures are yet to be available in many activity areas of insurance. There are even questions of adequacy of such empirical data. Lack of available data and information invariably means lack of awareness and interest on the part of the consuming public. Therefore, despite its apparent role in risk management and transfer, relatively few people in Bangladesh appear to be appreciating this role. Some who buy insurance (especially motor vehicle insurance) do so because it is made compulsory by law.

So far, studies on insurance marketing and consumption in Bangladesh have focused on the entire country. Little effort is made to disaggregate performance across the different states or geopolitical zones of the country to determine if there are location specific problems, differences or regional factors that could influence insurance consumption. This explains why the present study is concerned with identification of the key marketing and consumption inhibitors in Bangladesh with particular reference to Dhaka city. It is within this context that this study attempts an empirical investigation of those institutional factors that inhibit insurance consumption in Dhaka city.

\section{Objectives of the Study}

The general purpose of this study is to identify and examine those factors within insurance institutional framework that affect insurance consumption in Dhaka city. Thus, the specific objectives include:

(i) To determine the socio-economic characteristics of insurance consumers in Dhaka city.

(ii) To examine institutional factors inherent in insurance marketing framework that may affect insurance consumption.

(iii) To analyse the effect or relationship between the identified factors and insurance consumption.

(iv) To explore avenues upon which a vibrant insurance market could be developed in the Dhaka city.

\section{Research Questions}

This study was designed to provide answers to the following research questions:

(a) What is the socio-economic characteristic of insurance marketing framework in Dhaka city?

(b) Which institutional factors within insurance marketing framework do affect insurance consumption?

(c) What is the relationship between institutional characteristics (accessibility and prompt payment of claims, knowledge of the use and importance of insurance, professional activities of those selling insurance, nature of policy statement, and overall corporate image) on the one hand and insurance consumption on the other hand?

(d) In what way(s) can insurance marketing and consumption be improved in Dhaka city in particular and Bangladesh in general?

\section{Theoretical Framework}

In this section, an attempt is made to describe the theoretical foundations of the different factors hypothesized to drive the demand for and the supply of insurance as follows:

(a) Accessibility and Prompt Payment of Claims and Insurance Consumption:

Accessibility and prompt payment of claims is hypothesized to be positively related with insurance consumption. The basis for this expectation is that the more consumers are paid of their claims without unnecessary delays and bottlenecks, the more likely they will buy insurance. Akpan (2005) and Ibok (2006) found causal reasons for low insurance penetration as a result of institutional framework and identified factors such as delayed indemnification of risk victims with genuine insurance claims, lopsided distribution of insurance offices, lack of awareness, lack of proper education and fraudulent activities by those selling insurance as some of the factors affecting insurance penetration in the city.

(b) Knowledge, Awareness and Insurance Consumption:

Awareness and knowledge of the uses and importance of insurance is hypothesized to be positively related to insurance consumption. This is because the higher the level of one's awareness of a thing, the more likely the person will appreciate its value. The lack of sophistication or awareness and knowledge of insurance on the part of the consuming public has been identified as a major hindrance to insurance consumption. Majority of insurance consumers misunderstand the very purpose of insurance and this misunderstanding creates widespread difficulties for insurance marketing vis-à-vis consumption. Wilson (2004) observed that much of the dissatisfaction with insurance in Bangladesh is based on a faulty idea of what insurance is and how it operates. With this level of awareness, insurance patronage and consumption becomes a daunting task. This problem is even made worse by 
the high level of illiteracy among the citizenry (Oworen, 1993). An institutional bottleneck that affects insurance marketing and consumption as argued by Gowon (2004) is insufficient publicity and public awareness campaign by insurance companies.

\section{(c) Professionalism and Insurance Consumption:}

Professionalism constitutes the main force of insurance practice. Hence, it is hypothesized to be positively related with increased consumption. The unique nature of insurance industry should serve as the foundation for a distinctive marketing system in the insurance market (Gibbs, 1975; Nelli and Marshall, 1968; Green, Trieschmann and Gustanison, 1992). The agent is very central in insurance marketing process. While this is true, the relationship between the agent and the company they represent can be and is often varied. Because of the technical complications of the insurance products, it is particularly important that those selling insurance understand the contracts they are supposed to sell. Because a common problem associated with agency is the professional attitude of most insurance agencies. With little or no qualification, one can become an agent or broker. Worse still are the unwholesome practices by those selling insurance.

(d) Policy Statement and Insurance Consumption:

Policy Statement is hypothesized to be inversely related to insurance consumption. The assumption is that the higher the technicality involved in policy statement, the less likely consumers will buy insurance. The complex nature of most insurance policy statements are so complex for a literate citizen to understand, talk less of the less privileged and uneducated citizens. Gibbs (1975) suggested that insurance policy statements should be clear and simple, devoid of technical jargons and concise if its desired purpose is in any way to be achieved.

\section{(e) Corporate Image and Insurance Consumption:}

The image of anything can be described as the mental picture of that thing or being. Thus, corporate image is hypothesized to be positively related to insurance consumption. The basis for this expectant is that the better the image, the more likely people will like to be identified or do business with the company. The public image of an individual, organization or a professional group is therefore, the character of the person or body as perceived by the public. Since insurance is a business that thrives on confidence and integrity, its perception by the public is crucial to its development. However, the continuous call for improvement of the image and of practitioners is basically a cry for greater professionalism (Lijadu, 1988 and Mordi, 1990).

\section{Methodology}

This study was carried out in Dhaka city, Bangladesh. The respondents were insurance consumers resident in the study area. Primary data were sourced through administration of structured questionnaire. Two stage sampling technique was employed in data collection. In the first stage, four insurance companies were randomly selected from the list of insurance firms operating in Dhaka. In the second stage, 20 respondents were purposively selected from each insurance firm based on their availability as at the time of gathering the data. Altogether, 80 respondents constitute the sample for this study. The data were gathered with the help of insurance personnel who administered the questionnaire to respective insurance customers who visited their offices as at the time of gathering the information. But before administering the questionnaire, it was face validated with two experts from the Department of Marketing, Manarat International University. To test for internal consistency of the research instrument, Cronbach's alpha coefficient was used which yielded a reliability of 0.7882 or 79 percent. The questions were framed using Likert's scale of measurement ranging from strongly agree with 4 points to strongly disagree with 1 point. Questions eliciting information on respondents' socio-economic characteristics were also asked. Multiple regression analysis was used to examine the effect of the hypothesized factors on insurance consumption, while descriptive statistics was used to determine the socio-economic characteristics of insurance consumers. The multiple regression technique was explicitly represented in four functional forms such as linear, semi log, double log and exponential functions. The variables of interest with respect to insurance consumption were presented in an equation as follows:

$\mathrm{Y}=\mathrm{b}_{\mathrm{o}}+\mathrm{b}_{1} \mathrm{x}_{1}+\mathrm{b}_{2} \mathrm{x}_{2}+\mathrm{b}_{3} \mathrm{x}_{3}+\mathrm{b}_{4} \mathrm{x}_{4}+\mathrm{b}_{5} \mathrm{x}_{5}+\mathrm{e}_{\mathrm{i}}$---- (1)

Where: $\mathrm{Y} \quad=\quad$ Insurance Consumption (no. of units)

$\mathrm{X}_{1}=$ Accessibility and Prompt Payment of Claims

$\mathrm{X}_{2}=$ Knowledge and Awareness of Insurance

$\mathrm{X}_{3}=$ Activities of Insurance Marketers

$\mathrm{X}_{4}=$ Insurance Policy Statement

$\mathrm{X}_{5}=$ Insurance Corporate Image

$\mathrm{b}_{\mathrm{o}}=$ Intercept

$b_{1}-b_{5}=\quad$ Regression Coefficients

$\mathrm{e}_{\mathrm{i}} \quad=\quad$ Error Term

The Linear model which was the lead equation was chosen based on the performance of the coefficients of multiple determination and the number of significant variables. 


\section{Results and Discussion}

Socio-Economic Characteristics of Respondents:

Table-1 (see appendix table-i) shows that 6.25 percent of respondents are under 30 years of age while 10 percent of them are 45 years and above. Majority $(83.75 \%)$ of them are between the ages of (30-44). This indicates that insurance consumption cuts across different age groups, thus, age is not a barrier to buying insurance. Table- 1 also indicates that the largest proportion 77.5 percent of them are married, 15 percent of them are single while few of the 7.5 percent are widow or separated. Table-1 further revealed that 2.5 percent of the respondents received no formal education, 11.25 percent received primary education, 35 percent had secondary education, while 32.5 percent received tertiary education. The remaining 18.75 percent claimed to receive one form of education or the other. This information suggests that both literates and illiterates can be involved in the business of insurance consumption. Majority of the respondents 82.5 percent were males, while 17.5 percent were females (table-1). Furthermore, 60 percent of the respondents were public or civil servants. 25 percent were traders or farmers, while a very small percentage indicated to be involved in other ventures ( 15 percent).

\section{Institutional Factors Affecting Insurance Consumption:}

The empirical results showed that access and prompt payment of claims was positively related and statistically significant at $1 \%$ level of significance which showed that accessibility of insurance companies and prompt payment of genuine claims was a determinant of the amount of insurance bought by the consumers. Akpan (2005) and Ibok (2006) had earlier stressed that insurance consumption and patronage is a function of insurance location and the company's ability to pay genuine claims as at when due.

Knowledge of the importance of insurance and general awareness created by insurance companies was found to be positively related with insurance consumption and was statistically significant at $5 \%$ level of significance. This corroborates with the views of Wilson (2004), Oworen (1993) and Gowon (2004) who found in their respective studies that insufficient knowledge, awareness and publicity campaign hinders insurance operations.

The level of professionalism exhibited by insurance marketers was statistically significant and had positive contribution to insurance patronage. This however showed that activities of insurance marketers did influence insurance consumption and patronage. This is in agreement with Nelli and Marshall (1968) and Green's et al (1992) opinions that insurance practice calls for a high degree of professionalism, the absence of which has been the bane of the insurance industry.

Insurance policy statements was statistically significant at $1 \%$ level of significance and was negatively related with the value of -1.809 which implies that a $1 \%$ increase in the complexity of policy statement would generate a decrease in 0.809 in insurance consumption. Gibbs (1975) affirmed that policy statements should be made simple, clear and accurate and should be devoid of technical jargons in order to facilitate patronage as most consumers are not so sophisticated to understand the complex nature of most insurance policy statements.

Insurance image perception had a positive relationship and was statistically significant. The significant nature of this variable suggests that insurance activities, including advertisement should be aimed at building a good corporate image that could promote marketing and consumption. This corroborates Lijadu (1988) assertion that insurance industry should maintain the insured's public confidence and Mordi (1990) described the industry as having battered image and calls for managing insurance industry towards a better public image.

\section{Conclusion and Recommendations}

Based on the findings of this study, we conclude that there is indeed institutional factors that inhibit consumption in the city and that the apparently low insurance penetration in the city is as a result of dissatisfaction arising from the activities of insurance companies with regards to decayed indemnification of genuine claims, poor publicity and awareness campaign, unprofessional attitude of insurance marketers and the very complex and in comprehensible nature of insurance policy statement coupled with poor image perception of the industry by the public.

Considering the above facts, it is therefore recommended that:

i. Insurance companies must ensure that every genuine claim is paid promptly without unnecessary delay, while also making the whole business of insurance accessible to the consumers.

ii. The writing of policy statements is rather too mechanistic. Policy statements must be reduced and written in clear simple language. Every technical terminology expressed in the policy statement should be simplified, if possible in local languages.

iii. Knowledge of the importance and awareness of insurance has been a serious challenge to the insurance industry. Therefore more insurance education and publicity should be regularly carried out using available local media.

iv. Unprofessional and unwholesome activities by those selling insurance has created negative perception, thus creating negative image for the entire industry. Therefore to promote insurance practice and equip them for better customer service, everyone selling insurance must be made to possess standard academic 
and professional qualifications, with a well established ethics and code of conduct, and adequate enforcement mechanisms set up as a benchmark, for this is the only way the industry can maintain an acceptable professional identity.

v. Finally, to address the problem of better public image, it may be necessary to examine how the practitioners and indeed insurance marketers are perceived. Therefore consumer satisfaction survey is not only necessary but also crucial for the growth of a vibrant insurance market. This is necessary in view of the battered image of the industry among the consuming publics.

\section{Acknowledgement}

This paper was supported by the National Social Science Fund program of China (No. 16BJLO67).

\section{References}

1. Akpan, I. (2005). Principles of insurance and risk management, Uyo: Abaam Publishing Company, pp. 68 90 .

2. Catalan, M. Gregorio, I. A. and Alberto, M. (2000). Contractual savings or stock market development, which leads? World Bank Policy Research Working Paper, 12, pp. 24 - 27.

3. Gibbs, D. E. W. (1975). A study of individualism. New York: St. Martins Press, pp. $115-180$.

4. Gowon, Y. (2004). Excerpts from NICON interview, NICON Newsletter, No. 3, p. 12.

5. Green, M. R. Trieschmann, J. S. and Gustanison, S. G. (1992). Risks and insurance. $8^{\text {th }}$ ed. Cininnati: South Western Publishing, pp. $68-90$.

6. Ibok, N. I. (2006). Determinants of insurance consumption in the South-South zone, Nigeria. Unpublished Ph.D thesis, Faculty of Management Sciences, University of Calabar, Nigeria, pp. 16-24.

7. Impavido, G. and Musalem, Alberto (2000). Contractual savings, stock and asset markets. World Bank Policy Research Working Paper, No. 12, p. 46.

8. Lijadu, O. (1988). Maintaining the insuring public confidence: The role of insurance industry. Paper presented at the Insurance Seminar for Managers and Executives of Insurance Companies, Insurance and Brokers Firm and Financial Institutions, University of Lagos, Akoka, Nigeria, pp. $28-40$.

9. Mordi, O. (1990). Managing insurance industry towards a better public image. Journal of West African Insurance Companies Association (WAICA), xiv. Pp. 120 - 131.

10. Nelli, H. O. and Marshall, R. A. (1969). The private insurance business in the United States. Atlanta Bureau of Business and Economic Research Paper, No. 48, pp. $42-45$.

11. Njogu, E. O. (1991). Integrated marketing strategies. NICON Insurance Company of Nigeria Newsletter (3) pp. $14-20$.

12. Osaka, O. (1992). Insurance and the Nigerian economy: A anache. Ibadan: Hebook Publications, pp. 16 - 20.

13. Oworen, M. (1990). Sales forecasting in Iyanda O. (eds.), Marketing theory for practitioners. Ibadan: Heinemann, pp. $34-47$.

14. Soon, H. J. (1996). Life insurance and economic growth: Theoretical and empirical investigation. Ph.D Dissertation, Department of Economics, University of Nebraska.

15. Ward, D. and Zurbruegg, R. (2000). Does insurance promote economic growth? Evidence from OECD countries. Journal of Risk and Insurance, pp. $489-506$.

16. Webb, I. (2000). The effect of banking and insurance on the growth of capital. Ph.D Dissertation, College of Business Administration, Georgia State University, Atlanta, pp. 62 - 68.

17. Wilson, R. (2004). Modern business budgeting. New York: Alexander Hamilton, pp. $75-80$. 
APPENDIX -i

Table 1: Socio-Economic Characteristics of Insurance Consumers

\begin{tabular}{|c|c|c|}
\hline Characteristics & Frequency & Percentage \\
\hline $\begin{array}{c}\text { Age (years) } \\
<30 \\
30-34 \\
35-39 \\
40-44 \\
45 \text { and above } \\
\end{array}$ & $\begin{array}{c}5 \\
10 \\
15 \\
42 \\
8 \\
\end{array}$ & $\begin{array}{c}6.25 \\
12.5 \\
18.75 \\
52.5 \\
10 \\
\end{array}$ \\
\hline Total & 80 & 100 \\
\hline $\begin{array}{c}\text { Marital Status } \\
\text { Married } \\
\text { Single } \\
\text { Widow/Separated }\end{array}$ & $\begin{array}{c}62 \\
12 \\
6\end{array}$ & $\begin{array}{c}77.5 \\
15 \\
7.5\end{array}$ \\
\hline Total & 80 & 100 \\
\hline $\begin{array}{c}\text { Level of Literacy } \\
\text { No formal education } \\
\text { Primary education } \\
\text { Secondary education } \\
\text { Tertiary education } \\
\text { Others } \\
\end{array}$ & $\begin{array}{c}2 \\
9 \\
28 \\
26 \\
15 \\
\end{array}$ & $\begin{array}{c}2.5 \\
11.25 \\
35.00 \\
32.5 \\
18.75 \\
\end{array}$ \\
\hline Total & 80 & 100 \\
\hline $\begin{array}{c}\text { Sex } \\
\text { Male } \\
\text { Female }\end{array}$ & $\begin{array}{l}66 \\
14\end{array}$ & $\begin{array}{l}82.5 \\
17.5\end{array}$ \\
\hline Total & 80 & 100 \\
\hline $\begin{array}{c}\text { Main Occupation } \\
\text { Public/civil servants } \\
\text { Trading/farming } \\
\text { Others }\end{array}$ & $\begin{array}{l}48 \\
20 \\
12\end{array}$ & $\begin{array}{l}60 \\
25 \\
15\end{array}$ \\
\hline Total & 80 & 100 \\
\hline
\end{tabular}

Source: Field Survey, 2018

APPENDIX-ii

Table 2: Estimated Regression Results of Factors Influencing Insurance Consumption

\begin{tabular}{|c|c|c|c|c|}
\hline Institutional Factors & Linear Functions & $\begin{array}{c}\text { Semi-Log } \\
\text { Functions }\end{array}$ & $\begin{array}{c}\text { Double Log } \\
\text { Functions }\end{array}$ & $\begin{array}{c}\text { Exponential } \\
\text { Functions }\end{array}$ \\
\hline Constant & 15588.12 & 3.310 & 5.123 & 4.242 \\
$(2.987)^{* *}$ & $(4.283)^{* * *}$ & -0.004 \\
& $(6.043)^{* * *}$ & $(2.540)^{* *}$ & 0.080 & 4.725 \\
$(21.018)^{* * *}$ & $(3.900)^{* * *}$ \\
\hline $\mathrm{X}_{1}$ & 0.995 & $(0.091)$ & -1.070 & -0.019 \\
& $(11.179)^{* * *}$ & -0.065 & $(-1.465)$ & $0.158)$ \\
\hline $\mathrm{X}_{2}$ & 612.467 & $(-0.765)$ & 0.596 & $(2.786)^{* *}$ \\
\hline $\mathrm{X}_{3}$ & $(2.819)^{* * *}$ & 0.2950 & $(0.509)$ & 0.002 \\
& $(3.460 .23$ & $(2.458)^{* *}$ & 0.071 & $(1.700)$ \\
\hline $\mathrm{X}_{4}$ & -1.809 & 0.190 & $(0.697)$ & 0.037 \\
& $(5.724)^{* * *}$ & -0.486 & 5.633 & $(6.166)^{* * *}$ \\
\hline $\mathrm{X}_{5}$ & 660.642 & $(-4.339)^{* *}$ & $(5.867)^{* * *}$ & $\mathrm{R}^{2}=0.45$ \\
\hline
\end{tabular}

(Figures in brackets are the $\mathrm{t}-$ values)

$*, * *, * * *$ indicates probability level at $10 \%, 5 \%$ and $1 \%$ respectively.

Source: Field Survey, 2018 